\title{
Becoming an English Teacher: Voices from Nepal
}

\author{
Gopal Prasad Pandey, Ph.D. \\ Tribhuvan University, Kathmandu, Nepal \\ gpandeytu@gmail.com
}

DOI: http://doi.org/10.36892/ijlls.v2i3.337

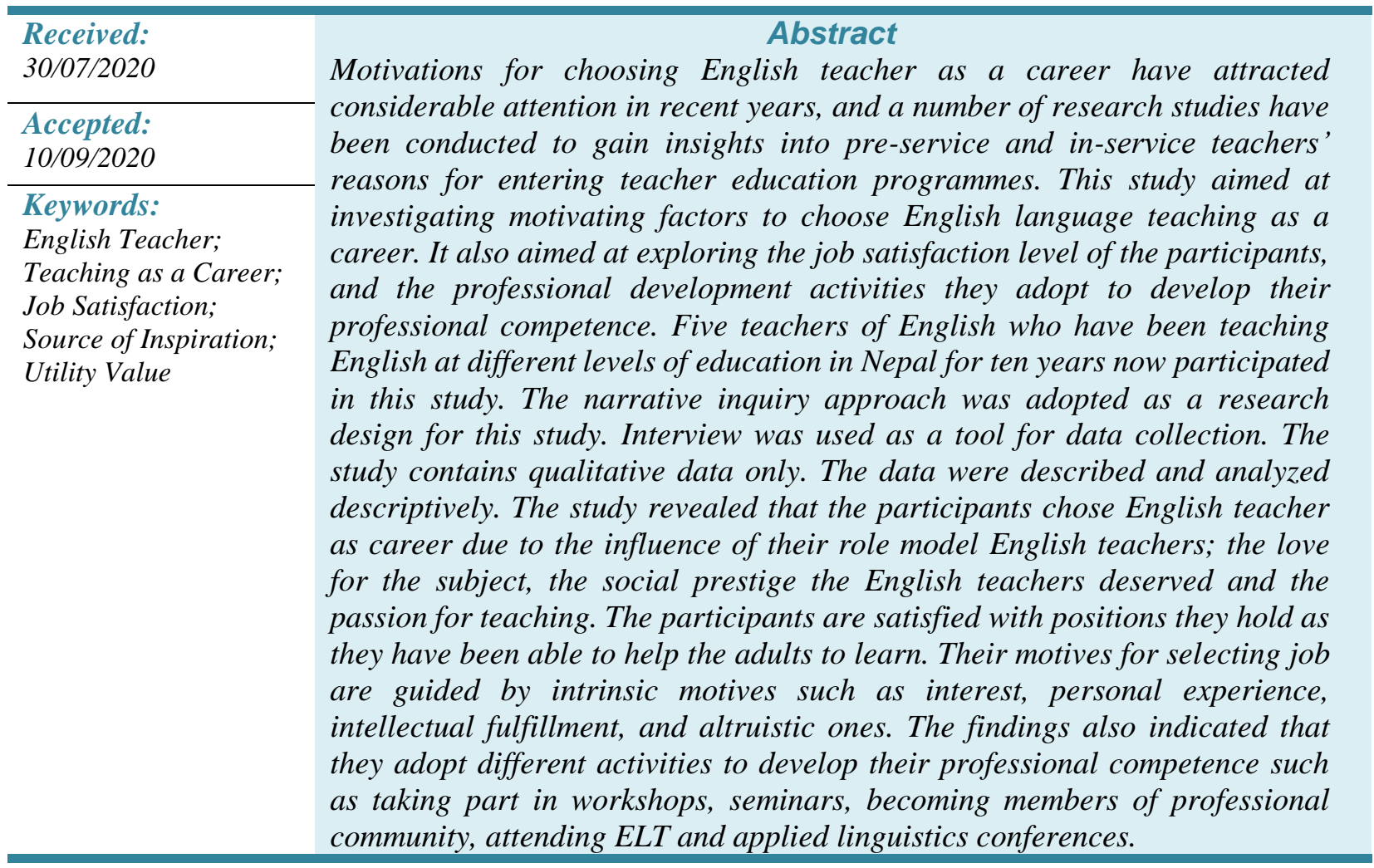

\section{INTRODUCTION}

Understanding and identifying teacher trainees' reasons and motivations deciding to become teachers seem to be crucial for teacher educators (Bruinsma \& Jansen, 2010; Mansfield, Wosnitza, \& Beltman, 2012; Richardson \& Watt, 2005). Motivations for choosing English teaching as a career have attracted considerable attention in recent years, and several research studies have been carried out to investigate pre-service and in-service teachers' reasons for entering teacher education programmes. The reasons for the selection of teaching as a career are many. Research studies mainly reveal three basic types or categories of motives for selecting teaching as a career: i) extrinsic motives such as salary, lengthy holidays; ii) intrinsic motives such as interest, personal experience, and intellectual fulfilment, and iii) altruistic motives as wanting to contribute to the growth of another individual (Brookhart \& Freeman, 1992, Richardson \& Watt, 2005; Rinke, 2008; Watt \& Richardson, 2008).

Although there is a huge number of research studies on teacher motivation in the field of general education, there are a few studies carried out on English language teachers' motivation for their career choice. Dornyei $(2001,2003)$ has also pointed out the scarcity of research on language teacher motivation. Research studies on second language teacher motivation have not offered a comprehensive picture of why individuals choose 
second/foreign language teaching as a career. In light of all these, the present study aims to unearth ELT trainees' motivations for becoming English language teachers in a Nepalese education context.

\section{LITERATURE REVIEW}

The section reviews theories of motivation, previous studies on teacher motivation and delineates motivations for choosing teaching as a career.

\section{Theories of Career Motivations}

In the 21 st century, knowledge has become the highest value commodity worldwide. With this reality, many countries have developed strategies to "carefully plan appropriate investments in human capital" (Kefela, 2010, p. 68) to improve their competitiveness. Developing countries, such as Brazil, China, Poland, Turkey and South Africa, initiated certain education reforms in order to become active players and to sustain their economic growth. As part of these reforms, teacher quality and education have become a hotly debated issue since research has affirmed that teacher quality is the most important factor associated with student performance (Darling-Hammond, 2000).

We have seen several theories of motivation. Theories of motivation have been developed since the 1950s. One of the earliest ones is Super's Self-concept Theory (1953) which drew upon the role of individuals' perception of self in choosing a career (Topkaya, 2012). According to the theory, the question "Who I am?" is a key factor that plays a significant role in individuals' choosing a profession. Holland (1959), on the other hand, named this factor as "self-knowledge" and claimed that a good occupational choice depends not only on individuals' accurate self-knowledge but also on accurate occupational knowledge (Topkaya, 2012). In addition to these, Bandura (1986) considers self-efficacy as an important source of motivation in the decision-making process. Johnson (1986, p. 55) states that there are three theories of motivation namely expectancy theory; equity theory and job enrichment theory. The expectancy-value theory suggests that the expectations of success and the subjective value of the task are major determinants of motivation for academic choices as well as career choices (Richardson \& Watt, 2005). Equity theory is based on the idea that individual's motivation level always correlates with his/her perception of equity, fairness and justice practiced by the management. Job enrichment involves motivating employees where a job is designed to have interesting and challenging tasks which can require more skill and can increase pay. According to Sinclair (2008) the prospective teachers are multi-motivated. Watt and Richardson (2007) used a comprehensive scale named Factors Influencing Teaching Choice (FIT-Choice). The scale heavily relied on the expectancy-value theory. They conducted the study with pre-service teachers enrolled in three Australian universities and found that perceived teaching abilities, the intrinsic value of teaching and the desire to make a social contribution were the highest rated motivations.

\section{Motivations for Choosing Teaching as a Career}

Motivation can be defined as "a drive which pushes someone to do things to achieve something" (Harmer, 2007, p. 51). For Brown (1994), motivation is "a term that is used to define the success or the failure of any complex task" (p.152). Motivation is thought to be responsible for "why people decide to do something, how long they are willing to sustain the activity and how hard they are going to pursue it" (Dornyei, 2001, p.8). Ryan and Deci (2000, p. 54) state that "to be motivated means to be moved to do something". The reasons for deciding to become teachers are intrinsic, extrinsic and altruistic. These motivations have been highlighted as the most important groups of reasons for deciding to teach (Brookhart \& Freeman, 1992). The recent research works on teacher motivations have concluded that the reasons for the choice of a teaching career founded on expectancy-value theory (Richardson \& Watt, 2006; Watt \& Richardson, 2007). Identifying which motivations relate to teacher 
engagement, commitment and persistence is a critical next step in light of workforce issues and pressures to understand the factors and processes underlying teacher quality (Watt \& Richardson, 2008).

People usually choose a particular career when it offers higher salaries, clearer pathways for career development, greater social prestige, and more agreeable working conditions (OECD, 2005; Ramsay, 2000). Still in many of the developing nations teaching does not satisfy these conditions. With increasing shortages of teachers, there has been a renewed interest in developed nations like the U.K., the United States, Europe, and Australia (OECD, 2005, as cited in Watt \& Richardson, 2008). There has been a growing interest in many of the developing nations in Asia in understanding what motivates people to choose teaching as a career and what motivates them to persist the job. By far the largest number of studies of teacher motivations has been conducted in the United States. The studies are mostly based on surveys. The results showed that the reasons for choosing teaching as a career are: intrinsic, extrinsic, and altruistic (Watt \& Richardson, 2008). Over the last five decades, there has been a growing interest in teacher motivation research in Asia. Many of the research conducted up until the early 1990s suggested that "altruistic, service-oriented goals and other intrinsic motivations are the sources of the primary reasons for why they chose teaching as a career" (Brookhart \& Freeman, 1992, p. 46). Reports say that teacher candidates choose to become teachers because they have a desire to work with children and adolescents. They love to help the children. This is one of the highly influential reasons in attracting people into a teaching career (Kyriacou \& Coulthard, 2000; Richardson \& Watt, 2006). According to the report of the Organization for Economic Cooperation and Development (2005);

A number of studies conducted with practising teachers from France, Australia, Belgium, Canada, the Netherlands, the Slovak Republic, and the U.K. confirmed that the most frequently nominated reasons for career choice among teachers was a desire to work with children and adolescents, together with the potential for the job to provide for intellectual fulfilment and a means by which to make a social contribution.

Some other studies conducted in countries such as Brunei, Zimbabwe and Jamaica have found that more extrinsic motivations such as salary, job security, and career status are important reasons for choosing a career in teaching (Watt \& Richardson, 2008, p. 409). Motivations for career choice, satisfaction and persistence are framed and shaped by different socio-cultural contexts as well.

In societies in some Asian countries, career success is measured by salary, career prestige, and social status. So, people decide to change their jobs and enter jobs that provide personal satisfaction and rewards. Some also look for the chances of making a social contribution when they change or take up a new career. In these societies and countries, a desire to keep learning is often seen as an "implausible choice" (Cr., 1990, as cited in Watt \& Richardson, 2008, p. 409. Among younger workers, there is now an embedded assumption that they will change their career several times over the course of their working lives. They change their professions as they find many options in the labour market. Mainly generations $\mathrm{X}$ and $\mathrm{Y}$ have very different options and are not likely to "fallback" on teaching due to a lack of career options to suit their talents and skills (Birrell \& Rapson, 2006, as cited in Watt \& Richardson, 2008). English learners in Nepal do not have ready access to using English as a tool of communication during their daily lives outside the classroom. This means that learning and teaching occur mostly in classrooms rather than during daily communication.

\section{Research Questions}

This study aimed at finding out the individual's reasons for choosing English teaching as a career. The study addressed the following questions:

1.What are the reasons for their (in-service English teachers) career choice? 


\section{How did they choose this profession?}

3.What professional development activities do they adopt to enhance their professional competence?

4.To what extent are they satisfied with their jobs?

5.What roles do they have to carry out as teachers of English (Job descriptions)?

\section{METHODOLOGY}

This study adopts a narrative inquiry method to examine the teachers' voice regarding how they become English teachers. According to Clandinin and Connelly (2000), narrative inquiry captures personal and human dimensions of experience over time and takes account of the relationship between individual experience and cultural context. Narrative researchers collect data about people's lives and construct meanings with the help of their experiences. In narrative research designs, researchers describe the lives of individuals, collect and tell stories about people's lives, and write narratives of individual experiences (Connelly \& Clandinin, 1990). According to Creswell (2016, p. 502), narrative research can be defined as "a distinct form of qualitative research, a narrative typically focuses on studying a single person, gathering data through the collection of stories, reporting individual experiences, and discussing the meaning of those experiences for the individual". Narrative inquiry is the interdisciplinary study of the activities involved in generating and analyzing stories of life experiences (e.g., life histories, narrative interviews, journals, diaries, memoirs, autobiographies, biographies) and reporting that kind of research (Schwandt, 2007, p. 204). Narrative research is the study of the lives of individuals as told through the stories of their experience, including a discussion of the meaning of those experiences for the individual.

\section{Research Participants}

Five English teachers took part in this study. They shared very similar sociolinguistic characteristics in terms of age, English proficiency, exposure to other languages, and the like. All the speakers were native speakers of Nepali. They also have experience of teaching English at levels of education in Nepal. Three of them are university teachers while two of them are teaching at secondary level schools for ten years now. They also work in different private colleges affiliated to Tribhuvan University as part-time lecturers. The participants were purposively selected as this is a narrative inquiry. Some of them worked as part-time English teachers while they were doing their master's degrees in English education at Tribhuvan University, Kathmandu. All the participants are males and their ages ranged between 30 and 40. All the participants are from outside of Kathmandu. Regarding their academic qualifications, they all have held M.Ed. in English education and currently pursuing their M.Phil. in English education from Graduate School of Education, Faculty of Education, Tribhuvan University, Kathmandu, Nepal.

\section{Research Tools}

The interview served as the main tool for data collection. After guidelines were prepared, the researcher visited the participants selected for this purpose. The questions focused on broad areas such as reasons why individuals chose English language teaching as a career, obstacles the teachers of English came across in their lives, professional development activities English teachers adopted to enhance their competence and efficiency. As they were interviewed their narratives were recorded using a mobile phone. The obtained data were analyzed thematically and descriptively. Thematic analysis is used in qualitative research and focuses on examining themes within data. Thematic analysis is one of the most common forms of analysis in qualitative research.

Interviews with five participants were conducted. Various topics related to the participants' experience in life as English teachers were covered. To elicit information, 
interviews were carried out as informal conversations to ensure a relaxed atmosphere so that more real-life stories could be extracted. Some open-ended questions prepared for this purpose were: Why and how did you become an English teacher? Why did you choose this profession? Who inspired you? What professional development activities do you adopt? To what extent are you satisfied with the job? What are your job responsibilities? They were also asked to describe their involvement in the community of practice, relationship with other teachers, overall teaching/learning environment in their workplaces, their overall perceptions towards the teaching of English.

\section{RESULTS AND DISCUSSION}

Data obtained from interviews were analyzed qualitatively. These data were analyzed and interpreted descriptively. All the three respondents were codified as T1, T2, T3, T4 and T5 for this study. The section is organized under the following subheadings: Source of inspiration, the journey of a teaching career, job satisfaction, the current status of the job, description and the obstacles they face.

\section{Source of inspiration}

Role model English teachers were the most mentioned sources of inspiration to choose ELT as a profession for the participants in this study. They were inspired by their prior teachers. Their teachers of English were role models, and the participants in this study wanted to adopt the profession. Intrinsic career value' and 'love for the subject matter itself were the other most frequently mentioned reasons why individuals chose language teaching as a career. They chose to teach as the profession deserved prestige and respect. Teachers of English get name and fame in the society. T1 (Govinda) said:

Becoming a teacher of English was not my compulsion rather it was my passion. In my childhood, I had a kind of passion to become a teacher of English and get a good name and fame in my life. At that time in my village teachers were respected everywhere and everybody used to greet them. So, I decided to be like those. Another important incident which encouraged me to become a teacher of English was the personality of the secondary level teacher of English. Mr Airy was our English teacher, he had very good English and he was quite a young energetic person in the school. He was very hardworking and inspiring.

T2 (Tarapati) has a similar opinion regarding the reason why he chose ELT as a profession. He said: "My decision to become an English teacher was not by chance but by choice. It was the direct result of having wonderful teachers of English and supportive parents who always motivated me to get higher education." They inspired him to achieve his dream and aspiration through education. He further said "I was lucky to have many passionate teachers in my childhood who boosted my love for English. Indeed, I was extremely influenced by Prof. Bhandari, who taught me English Phonetics and Phonology at college. His excellent English with native-like accent attracted me to be like him." All the participants studied English from grade four. They passed their SLC examinations from state-owned schools. So their English starts in grade four. T3 (Barun) studied English from grade four as other participants did. Mr. Joshi taught him English for the first time as an English teacher. Though he studied English for the first time, he didn't feel any difficulty in English because of child-friendly techniques of teaching. He still remembers the way he had been taught. He used to encourage him to learn English. He said: "He used to employ many techniques to motivate us. He involved the students in classroom interaction. His methods of teaching English motivated me in learning English." He remembers and appreciates his teacher in the following way. T3 (Barun) continued: "He taught us English from grade four to grade seven. I along with my other classmates liked him very much because of his good teaching techniques. I was too much impressed by his personality and his teaching style. There grew the feeling of becoming a 
teacher of English in my mind like him. Later on, there grew a keen interest in English subject." Even the affection showed by the students in their initial years made them continue this profession. T4( Mazzakir) stated: "the affection and respect the students showed towards me also attracted me to this profession. Besides, my guru and guide of life Prof. Mishra and my elder brother are two living creatures who encouraged me to this profession. The lifestyles, encouraging words of my professor and his pat on the back are still vivid in my mind." The stories of teacher participants tell us that their career choices were guided by their role model teachers of English and the intrinsic values like passion and interest.

\section{The Journey of Teaching Career}

All the participants in this study graduated from state owned government schools. The minimum qualification to become a secondary level teacher of English in Nepal is bachelor's degree in English education. For university-level teaching positions, one needs to hold an M.A or M.Ed. in English. Masters' degree in English education is a must for an English lecturer's position in education campuses. All the participants in this study have earned M.Ed. degrees in English education. They obtained their basic and secondary level education from government schools. Their appetite and dream of becoming teachers of English forced them to get admissions in proficiency certificate level majoring English. Their dream of becoming Khaire (native-like teacher) like the speaker of English was yet to be fulfilled. So, after they passed their certificate level examinations, they admitted to B.Ed. programmes of Tribhuvan University. They left no stone unturned to brush up their English as they wanted to become teachers of English in their life. They wanted to be like their model English teachers. To brush up and strengthen their English, one of the participants even joined the language centre. T1 (Govinda) said "I did not leave any stone unturned to make my English good so that I joined the English language coaching center where I got a good environment to practise my English. Joining that language center can be taken as the foundation for fulfilling my impulsion of becoming a fluent speaker." He further stated: "Studying in B.Ed. at S.N. Multiple campuses was a turning point in my life. During my bachelors' degree, I got a group of friends who have similar kind of the thrust of speaking English. "We decided to use the English language all the time in campus premise and even in our informal talks", T3 said. They made their campus 'English only zone'. They faced many problems but did not stop marching ahead. During their stay at the campus, at times there used to be various programmes. They took part in the programmes so that they could develop confidence in themselves. In this connection, T2 (Tarapati) reported: "I used to be master of the ceremony which helped me to strengthen my confidence level." T2 further stated "One day I delivered a public speech in my college in front of more than 500 students in English. From that day I knew that I could speak in English fluently." After their B.Ed. degrees they joined schools at their places to teach English. They were offered jobs. They started dreaming to earn higher degrees and social positions and joined M.Ed. programmes at the university campus, Kirtipur, Tribhuvan University, Kathmandu. After they earned their M.Ed. in English Education spending two productive years in Kathmandu, they went back to their home towns and looked for the jobs. In the beginning, they taught at schools. After some months, they were offered jobs at universities. Now they have been teaching at different universities. Their twoyear stay in Kathmandu proved to be a milestone in the journey of their teaching careers.

Having successfully completed master's degree from Tribhuvan University, they (three of them) took up university-level teaching positions. They have been teaching English at different levels. Now they feel good and happy. One of the participants T2 (Tarapati) said I feel good and happy especially when my students understand what I teach." They employ different teaching techniques to teach their students. They have learnt these techniques in their M.Ed. courses. They also use additional sources in the classroom a part from the textbooks. In addition to teaching, they also engage in researches. They have completed some 
mini-research projects financed by their universities. Thus their journey starts immediately as soon as they pass their higher secondary level examinations.

\section{Job Satisfaction}

Teachers are satisfied with their jobs and positions they hold. They think that they have chosen the right jobs. They have been teaching English at universities and schools for ten years now. T2 said:

I love the profession because it provides me with opportunities to work with young people every day. What I found most satisfying about teaching is that I am helping people to learn. I taught in high school for a year. It was satisfying to teach small children, but I found university teaching really wonderful because it is the most respectable job as you get admired by so many young students.

They get enough time to spend with their family and friends as they are teaching students at the university level. "The most important thing is you remain updated," T2 said. They are fully satisfied with the job as they get a lot of opportunities to visit different places home and abroad, to brush up their professional efficacy and personal experience (T1 Govinda).

It can be concluded from the narratives that teachers of English are satisfied with the job they have undertaken. The most satisfying thing they find in their professions is that they can help the adults learn. That is, they can contribute to the development of other individuals.

\section{Professional Development Activities}

Teachers should keep abreast of the new changes in their field of education and language teaching. They need to continue learning to keep up-to-date with the constant development in the field of education. This type of learning is often referred to as professional development as it aims to enhance the teacher's professional competence and efficiency.

The most important of all factors is the teachers' motivation. The teacher himself/herself has to perceive it positively. A teacher who perceives professional development positively is eager to attain new knowledge and skills. They looked forward to trying new things in their teaching and were positive and eager to attain new knowledge, skills, attitudes, values and dispositions.

Becoming a teacher is the most challenging job. T1 (Govinda) said, "I think we need to be updated every time." Updating with recent trends in teaching and research is one of the pivotal facets of professional development. Therefore, they spend few hours in reading books related to the subject so that they can update themselves with the new trends and as well as get in touch with world happenings. T1 said; "I frequently read journals of Nepal and TESOL online journal to update myself. I am a life member of Nepal English Language Teachers' Association (NELTA). I have attended so many workshops and conferences of NELTA. I have presented many papers at NELTA conference and IATEFL, UK. I am heading a District branch of NELTA and organizing various training sessions in that region for the professional development of teachers. I have attended so many training sessions, workshops, seminars organized by the university." They have written some textbooks of English for undergraduate level. As they are highly interested in research, they have conducted some mini-researches as well. "I have written nearly half dozen articles on different journals published by the university", T3 reported. T4 (Mazzakir) said: I am also a life member of NELTA (Nepal English Language Teachers' Association). Annual conferences of NELTA have created a common platform for all the ELT experts to share different ideas in that they have got from their classrooms. T3 (Barun) said: "For my professional development of professional competence, I attended many short and long term teachers' professional development training sessions run by the government and non-government training programs." He added "I have 
taken part in training and workshop programmes conducted by Secondary Education Development Center (SEDU) where Mr. Bhatt was a trainer who used to make training enjoyable and his training techniques are still fresh in my mind." He said that he also participated in NELTA conferences annually and took part in different teacher professional development activities organized by NELTA, the British Council, and different government and non-government organizations. He takes part in the ELT and Applied Linguistics conference every year organized by the Department of English Education. Teachers of English also have realized the importance of professional development in the field of EFL teacher education. One of the participants has established a school in his hometown and encourages teachers to take part in teacher professional development activities such as workshops, seminars, pieces of training, and teacher support groups. The school organizes workshops and training programmes for the enhancement of professional competence of teachers. He also encourages teachers to involve in action research. Teachers also take part in these programs. They get a chance to share their experiences with each other.

Thus teachers believed professional development activities updated their professional knowledge and help them to enhance the quality of their teaching and learning. They take part in workshops, seminars and conferences. They also have become members of different professional organizations.

\section{Current Status}

All the participants in this study have been teaching more than ten years. They have been teaching with zeal and enthusiasm. They believe that they have a similar kind of passion they had during their early days. Generally, they take 5/6 classes a day at graduate and undergraduate levels. They really enjoy their job. They have improved a lot. In this regard, T1 said: "My impression is good from the beginning of my profession as I show my honesty and dedication to my profession. I also have got lots of opportunities to refine myself in the profession. My desire to learn and teach has been fulfilled." In addition to teaching, they also have to supervise the students' thesis writing. Supervising researches of students provided them with a lot of insights in the field of research. Most of the time, they remain busy in college for taking classes and correcting students' assignments and theses. Other participants have similar opinions regarding their choice of English Language Teaching as a career. Thus, they have been teaching with zeal and enthusiasm. They think that they are contributing to the society. They are respected and loved by everyone.

\section{Job Description}

In the teacher-centered classroom, the role of the teacher is to deliver information to students and test the students' ability to remember and understand that information. The students are passive listeners in the classrooms. They understand and remember information transmitted by the teacher but cannot analyze, apply, evaluate, or create information.

Teaching is a very dynamic profession. The way we teach and learn changes year to year depending upon what we teach and the type of students we have. Nepalese classes we teach have remained the same for the last five decades. Our classrooms are still teachercentred. The main challenge teachers have to face is that they have to abreast with the newest ideas of the subject they have been teaching. T1 said:

In my opinion, teaching is the most difficult job in the world as a teacher has to satisfy the hundreds of the students who have different mindsets, minds and attitudes. A teacher has to be updated in each and every moment of life because in our society teachers are taken as role models.

He further said; the life of a teacher is full of restrictions; they cannot do any wrong deeds in their life, they must be very cautious in each and every word they speak or write." This is 
because society considers the teacher as the most knowledgeable person among others, so a teacher cannot go against social belief.

\section{Obstacles}

This view of a teacher makes them happy in one hand but on the other hand, it makes them sad due to various obstacles they come across in their lives. T1 said, "A teacher cannot live his/her own style of life." These restrictions of life really hinder their lives. "I get up early in the morning and get into the university and come back to my house at night, where I do not have time for my family and friends", T1 stated. The teachers are overloaded. In addition, unnecessary political pressure in the university has made the teacher's job challenging. T1 further said "Teachers have been scapegoats of the society at present; the image of teacher is being ruined by some political teachers." Teachers have become more political than academic ones. To make the politician's happy teachers go against professional ethics which has completely ruined the academic environment of the university. This kind of environment is unfavourable for those teachers who want to be really professional. T1 further justified:

Such kind of environment is not only seen in my university but it is widespread all over the nation. Schools, colleges or universities are engulfed by dirty politics. T1 continued: There are no academic gossips in the staff rooms rather they are divided into different political poles and talk in support of their leaders blindly. The quality of students is decreasing day by day.

T2 said: "In my opinion, teachers are responsible for this situation. They should be academicians or professional rather than politician. T4 (Barun) said "I do not find any teacher in my campus who is fully devoted to his/her profession, flattering their political leaders is their daily job. This horrible scenario of teaching profession may lead the nation towards failure." Political interference in the academic arena has become a great hindrance to development of professionalism in Nepal. Even university teachers do not deserve prestige as they have become mere cadres of political parties. Consequently, there is decrease in professionalism in the Nepalese academia. This is one of reasons behind the increase of disrespect to teachers. T1 (Govinda) said "I think directly and indirectly governmental policies are also responsible for this scenario. Therefore, I think government has to change policies regarding teaching and teachers, so that quality can be enhanced." Thus, overload, political interference in the academia, busy life and government's reluctance to improve the quality of education are some of the obstacles teachers of English face in their profession.

\section{CONCLUSION AND IMPLICATIONS}

The main aim of the study was to explore individuals' motives to enter teaching of English. Five teachers of English teaching at different schools and colleges of Nepal took part in this study. Most noticeably, the motives for selecting English language teaching as a career are influenced by intrinsic career values. They have chosen this profession as they like English and love the profession. Along with their passion to become teachers of English, they were also influenced by their parents and teachers. The factor 'prior teacher role model' was found to be dominant in choosing the profession. They were influenced by their role model teachers. They decided to persist this profession as they liked their teachers, the way they taught, and the way they behaved. It was also found that teachers are fully satisfied with their jobs. This factor appears to be a significant factor in career choice decisions. They have decided to choose this profession not by chance but by choice. They have not considered it not as a fallback career. This is their passion which contradicts the general public. Generally, people think that teaching is a poor and implausible choice in Nepal. Similarly, social utility values (shape future of children/adolescents, enhance social equity, make a social contribution, work with children/adolescents) was another reason why they chose this career. 
This is incongruence with the findings of Yong (1995). There are also some extrinsic factors as well that attracted them to become teachers of English. They wanted to become teachers of English as they wanted to earn money at least to earn their livings. The social positions and the prestige their prior teachers deserved also attracted them to choose this profession. Participants were motivated to become teachers of English for several reasons namely selfperceptions, personal utility values (job security and time availability for family) and socialization influences. This coincides with the findings of Sinclair (2008).

\section{REFERENCES}

Bandura, A. (1986). The explanatory and predictive scope of self-efficacy theory. Journal of Clinical and Social Psychology 4, 359-373.

Brookhart, S. M., \& Freeman, D. J. (1992). Characteristics of entering teacher candidates. Review of Educational Research, 62(1), 37-60.

Brown, H.D. (1994). Principles of language learning and teaching. New Jersey: Prentice Hall Regents.

Bruinsma, M., \& Jansen, E. P.W.A. (2010). Is the motivation to become a teacher related to preservice teachers' intentions to remain in the profession? European Journal of Teacher Education, 33(2), 185-200.

Clandinin, D.J., \& Connelly, F.M. (2000). Narrative inquiry: Experience and story in qualitative research. Sans Francisco: Jossey-Bass.

Connelly, F.M.,\& Clandinin, D.J. (1990). Stories of experience and narrative inquiry. Educational Researcher, 19(5), 2-14.

Creswell, J.W. (2016). Educational research: Planning, conducting, and evaluating quantitative and qualitative research. Boston: Pearson.

Darling-Hammond L 2000. Teacher quality and student achievement: A review of state policy evidence. Educational Policy Analysis Archives, 8, 1-44.

Dörnyei, Z. (2001). Teaching and researching motivation. Essex: Pearson Education Limited.

Dörnyei, Z. (2003). Attitudes, orientations, and motivations in language learning: advances in theory, research, and applications. In Z. Dörnyei (Ed.), Attitudes, orientations, and motivations in language learning: Advances in theory research and applications (pp.3 32). Boston: Blackwell Publishing.

Harmer, J. (2007). The practice of English language teaching (4th. ed.). Harlow: Longman ELT.

Holland, J. L. (1959). A theory of vocational choice. Journal of Counseling Psychology, 6 (1), 3545.

Johnson, S. M. (1986). Incentives for Teachers: What Motivates, What Matter. Educational Administration Quarterly, 22(3), 54-79.

Kefela, G.T. (2010). Knowledge-Based economy and society has become a vital commodity to countries. International Journal of Educational Research and Technology, 1(2), 68-75.

Kyriacou, C., \& Coulthard, M. (2000). Undergraduates' views of teaching as a career choice. Journal of Education for Teaching, 26 (2), 117-126.

Mansfield, C., Wosnitza, M., \& Beltman, S. (2012). Goals for teaching: Towards a framework for examining motivation of graduating teachers. Australian Journal of Educational \& Developmental Psychology, 12, 21-34. 
Organization for Economic Cooperation and Development. (2005). Teachers matter: Attracting, developing and retaining effective teachers. Paris:Organization for Economic Cooperation and Development.

Ramsay, G. (2000). Quality matters. Revitalising teaching: Critical times, critical choices. Report of the review of teacher education. Sydney, Australia: NSW Department of Education and Training.

Richardson, P. W., \& Watt, H. M. G. (2005). 'I've decided to become a teacher': influences on career change. Teaching and Teacher Education, 21(5), 475-489.

Richardson, P. W., \& Watt, H. M. G. (2006). Who chooses teaching and why? Profiling characteristics and motivations across three Australian universities. Asia-Pacific Journal of Teacher Education, 34(1), 27-56

Rinke, C. (2008). Understanding teachers' careers: Linking professional life to professional path. Educational Research Reviews, 3, 1-13.

Ryan, R.M., \& Deci, E.L. (2000). Self-determination theory and the facilitation of intrinsic motivation, social development, and well-being. American Psychologist, 55, 68-78.

Schwandt, T. A. (2007). The Sage dictionary of qualitative inquiry. Thousand Oaks, CA: Sage Publications.

Sinclair, C. (2008). Initial and changing student teacher motivation and commitment to teaching. Asia-Pacific Journal of Teacher Education, 36(2), 79-104.

Topkaya, E.Z. (2012). Choosing Teaching as a Career: Motivations of Pre-service English Teachers in Turkey. Journal of Language Teaching and Research, 3(1),126-13. doi:10.4304/jltr.3.1.126-134

Watt, H. M. G., \& Richardson, P. W. (2007). Motivational factors influencing teaching as a career choice: Development and validation of the FIT Choice scale. The Journal of Experimental Education, 75(3), 167-202.

Watt, H. M. G., \& Richardson, P. W. (2008). Motivation for teaching. Learning and Instruction, 18 (5), 405-407.

Yong, B. C. S. (1995). Teacher trainees' motives for entering into a teaching career in Brunei Darussalam. Teaching and Teacher Education, 11(3), 275-280.

\section{$\underline{A U T H O R ' S B I O}$}

Dr. Gopal Prasad Pandey is Reader in English Education at Tribhuvan University (TU), Kathmandu, Nepal where he has been teaching ELT and Applied linguistics courses for two decades now. Dr. Pandey is currently the Head of the Department of English Education, University Campus, TU. His interest areas include critical discourse analysis, ESP studies, syllabus design, and materials production and teacher professional development. 